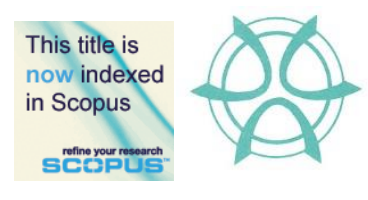

\title{
WATER FOOTPRINT OF CROP PRODUCTION IN TEHRAN PROVINCE
}

\author{
Somayeh Rezaei Kalvani ${ }^{1}$, Amir Hamzah Sharaai ${ }^{2}$, Latifah Abd Manaf ${ }^{3}$, \\ \& Amir Hossein Hamidian ${ }^{4}$ \\ ${ }^{1,2}$ Faculty of Environmental Studies \\ UNIVERSITI PUTRA MALAYSIA \\ ${ }^{3}$ Faculty of Natural Resources \\ UNIVERSITI of TEHRAN \\ ${ }_{4}^{4}$ Institute of Plantation Studies \\ UNIVERSITI PUTRA MALAYSIA
}

\begin{abstract}
Evaluation of supply chain of water consumption contributes toward reducing water scarcity, as it allows for increased water productivity in the agricultural sector. Water Footprint (WF) is a powerful tool for water management; it accounts for the volume of water consumption at high spatial and temporal resolution. The objective of this research is to investigate the water footprint trend of crop production in Tehran from 2008 to 2015 and to assess blue water scarcity in the agricultural sector. Water consumption of crop production was evaluated based on the WF method. Evapotranspiration was evaluated by applying the CROPWAT model. Blue water scarcity was evaluated using the blue water footprint-to-blue water availability formula. The results demonstrate that pistachio, cotton, walnut, almond, and wheat have a large WF, amounting to $11.111 \mathrm{~m}^{3} / \mathrm{kg}, 4,703 \mathrm{~m}^{3} / \mathrm{kg}, 3,932 \mathrm{~m}^{3} / \mathrm{kg}, 3,217 \mathrm{~m}^{3} / \mathrm{kg}$, and $1.817 \mathrm{~m}^{3} / \mathrm{kg}$, respectively. Agricultural blue water scarcity amounted to 0.6 (severe water stress class) (2015-2016). Agricultural water consumption in Tehran is unsustainable since it contributes to severe blue water scarcity. Tehran should reduce agricultural water scarcity by reducing the water footprint of the agricultural sector.
\end{abstract}

Keywords: blue water footprint, CROPWAT model, green water footprint, water consumption; water management 
Somayeh Rezaei Kalvani, Amir Hamzah Sharaai, Latifah Manaf, \& Amir Hossein Hamidian

Water Footprint of Crop Production in Tehran Province

\section{INTRODUCTION}

Water is life. This statement refers to the worth of water for individuals and life on the planet. Water is essential for human beings, and thus access to clean water is considered a human right. Water crisis is a crucial issue because approximately 1.2 billion people face severe water scarcity (Rijsberman, 2004).

A variety of methods to evaluate water use in the supply chain have been developed. Allen, Pereira, Raes and Smith (1998) introduced virtual water, which accounts for water consumption in other countries. Hoekstra and Hung (2002) introduced a tool to measure water consumption in the supply chain of products with regard to time and location, which is known as the water footprint concept. The International Standard Organisation (ISO) provides guidelines for water footprint assessment, known as ISO14046.

To date, limited WF studies have been done in Iran but all are based on a national scale. This study addresses this gap by examining the water footprint of crop production in Tehran province and comparing the trend in water footprint during the period 2008-2015. Then, blue water stress was evaluated.

Iran is facing severe water scarcity. Water use in Iran was approximately 4.5 billion $\mathrm{m}^{3}$ in 1963 . Consumption has increased dramatically to more than 93 billion $\mathrm{m}^{3}$ in 2006 but per capita water use was declined sharply (Zehtabian, Khosravi, \& Ghodsi, 2009). A country will be identified as a water scarcity area when water availability for one person is lower than $1,700 \mathrm{~m}^{3}$ (Rockstrom \& Falkenmark, 2006). Iran with a population of more than 70 million people is among the countries facing the most severe water shortage in the world (Madani, 2014). It is claimed that approximately $90 \%$ of limited water resources in Iran is allocated to the inefficient agricultural sector (Madani, 2014). Therefore, it is essential to account for the water consumption in Tehran to reduce its negative effect on water resources. This study can help decision makers to prioritise water consumption in order to achieve optimal water consumption in the agricultural sector (Tillotson, Liu, Guan, \& Pahlow, 2014).

The purpose of this study is to assess the water footprint of different crop products and compare the water footprint trend from 2008 to 2015. Besides that, blue water scarcity was evaluated to identify the status of blue water resource in terms of sustainability.

\section{METHODOLOGY}

In this study, the water footprint method created by Hoekstra and Hung (2002) is used because this approach is more comprehensive assessment for evaluating water consumption at high spatial and temporal resolution. In this study, the blue and green water footprints for the production of crops in Tehran province were evaluated based on the Hoekstra et al. approach (Hoekstra, Chapagain, Aldaya, $\&$ Mekonne, 2011). The annual blue and green water footprint of apple, apricot, cherry, sour cherry, pear, plum, almond, walnut, pistachio, pomegranate, peach, 
wheat, alfalfa, barley, bean, cotton, maize, tomato, potato, grapes, melon, watermelon, and onion were evaluated from 2007 to 2015. The blue water footprint of growing crops is the fraction of water use by crop CWU blue $\left(\mathrm{m}^{3} / \mathrm{ha}\right)$ to the yield (ton/ha.), as per Equation (1) (Hoekstra et al., 2011). The green water footprint is evaluated using a similar method - Equation (2) (Hoekstra et al., 2011).

$$
\begin{array}{ll}
\text { WF blue }=\frac{\text { CWU blue }}{\mathrm{Y}} & \text { Equation (1) } \\
\mathrm{WF} \text { green }=\frac{\mathrm{CWU} \text { green }}{\mathrm{Y}} & \text { Equation (2) }
\end{array}
$$

Crop water use (CWU) is assessed based on evapotranspiration (ET). CWU per crop is evaluated. CWU is defined as the sum of water consumption for each crop during the growing time in cubic meters to hectare $\left(\mathrm{m}^{3} / \mathrm{ha}\right)$ (Hoekstra et al., 2011). Crop water use (CWUblue and CWUgreen) is accounted for by multiplying ET blue and ET green with 10, respectively (Hoekstra et al., 2011) (Equations (3) and (4)). The evaluation of ET was done during crop growth from planting day to harvesting day. Lgp refers to length of the growing period. The value of 10 is used to convert the unit $\mathrm{mm}$ to $\mathrm{m}^{3} / \mathrm{ha}$.

$$
\begin{array}{ll}
\mathrm{CWU}_{\text {blue }}=10 \sum_{\mathrm{d}=1}^{\mathrm{lgp}} \text { ET blue } & \text { Equation (3) } \\
\mathrm{CWU}_{\text {green }}=10 \sum_{\mathrm{d}=1}^{\mathrm{lg}} \mathrm{ET} \text { green } & \text { Equation (4) }
\end{array}
$$

Evaluation of ET was laborious and time consuming. In this study, $\mathrm{ET}_{\text {blue }}$ and $\mathrm{ET}_{\text {green }}$ were simulated using the CROPWAT model (Allen et al., 1998). The requirements for this software are climate data and crop parameters. The output from the CROPWAT software includes evapotranspiration, effective rainfall, and irrigation requirements. $\mathrm{ET}_{\text {blue }}$ was determined by subtracting effective rainfall from evapotranspiration. However, the green water footprint is the minimum effective rainfall and evapotranspiration (Hoekstra et al., 2011).

\section{Water Footprint of Crop Production}

The water footprint of crop production was assessed by multiplying crop water footprint $\left(\mathrm{m}^{3} / \mathrm{ton}\right)$ with volume of production (ton/year) in a year. In this study, the green and blue water footprints were calculated by multiplying water footprint with annual production ((Equations (5) and (6)) (Boer, 2014). 
Somayeh Rezaei Kalvani, Amir Hamzah Sharaai, Latifah Manaf, \& Amir Hossein Hamidian

Water Footprint of Crop Production in Tehran Province

WFblue $=\mathrm{WFp}$, blue $\times$ production

Equation (5)

$\mathrm{WF}$ green $=\mathrm{WFp}$, green $\times$ production

Equation (6)

The agricultural water scarcity indices are the ratio of water withdrawal to water availability (Xinchun et al., 2017). In this study, agricultural blue water scarcity $\left(\mathrm{AWS}_{\text {blue }}\right)$ was evaluated as the fraction of agricultural blue water footprint to the agricultural blue water availability ( $\left(\mathrm{AWA} \mathrm{A}_{\text {blue }}\right)$, as per Equation (7).

Water scarcity was ranked as follows: WSI $<0.1=$ low water stress; $0.1<\mathrm{WSI}<0.5=$ moderate $0.5<\mathrm{WSI}<0.9=$ high water stress, and WSI $>0.9=$ very high water stress.

$$
\mathrm{AWS}_{\text {blue }}=\frac{\mathrm{AWF}_{\text {blue }}}{\mathrm{AWA} \mathrm{A}_{\text {blue }}}
$$

Equation (7)

AWA $_{\text {blue }}$ is accounted for using Equation (8) (Xinchun et al., 2017).

$$
\mathrm{AWA}_{\text {blue }}=\frac{\mathrm{AWU}_{\text {blue }} \times \mathrm{WR}_{\text {blue }}}{\mathrm{WU}_{\text {blue }}}
$$

Equation (8)

Where, $\mathrm{AWU} \mathrm{U}_{\text {blue, }}, \mathrm{WR}_{\text {blue }}$ and $\mathrm{WU}_{\text {blue }}$ are the agricultural water use, blue water resource, and blue water used by all sectors, respectively.

\section{RESULTS}

The results illustrate the average virtual water of different crops cultivated in Tehran in 2007-2014. The virtual water of different crops depends on productivity and water requirement. In Tehran, pistachio consumed high virtual water. The blue and green virtual water for production of pistachio was $756 \mathrm{~m}^{3} /$ ton and $10,355 \mathrm{~m}^{3} /$ ton, respectively. Additionally, the green and blue virtual water for the production of cotton was $410 \mathrm{~m}^{3} /$ ton and $4293 \mathrm{~m}^{3} / \mathrm{ton}$, respectively. Besides that, cotton, walnut, almond, and wheat had large total green and blue WF, amounting to $11.111 \mathrm{~m}^{3} / \mathrm{kg}, 4,703 \mathrm{~m}^{3} / \mathrm{kg}, 3,932$ $\mathrm{m}^{3} / \mathrm{kg}, 3,217 \mathrm{~m}^{3} / \mathrm{kg}$, and $1.817 \mathrm{~m}^{3} / \mathrm{kg}$, respectively (Figure 1 ). 
PLANNING MALAYSIA

Journal of the Malaysia Institute of Planners (2019)

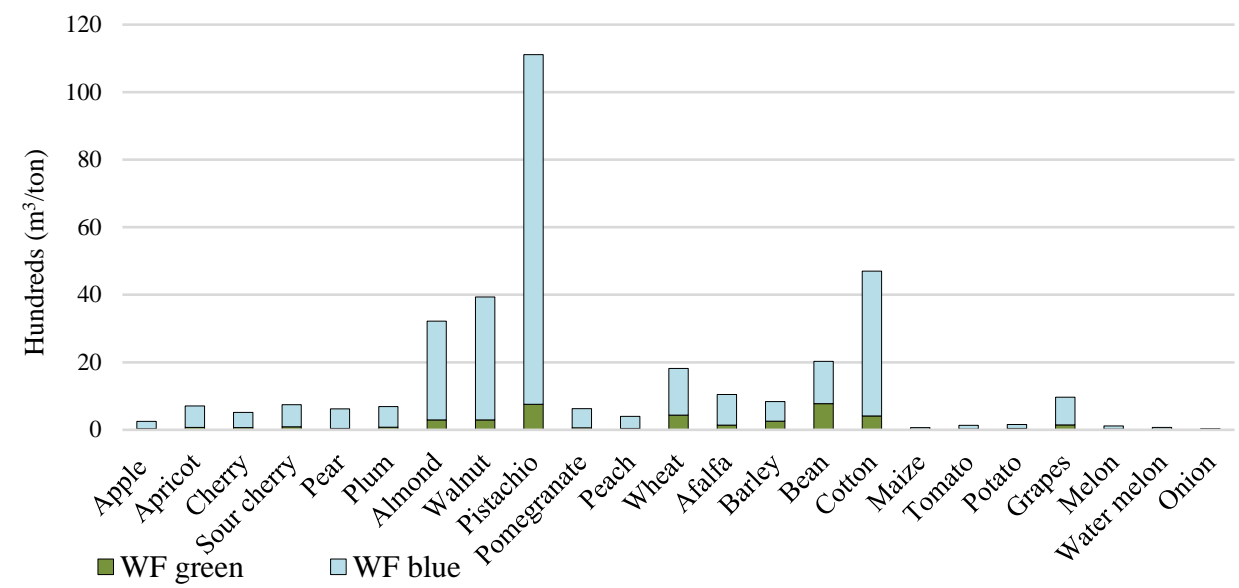

Figure 1 The average virtual water $\left(\mathrm{m}^{3} / \mathrm{ton}\right)$ of different crop productions in Tehran province, 2007-2015

The average blue and green water footprints (2008-2015) of barley was $844,204,277.33 \mathrm{~m}^{3} /$ year, consuming $33 \%$ of water resources in the agriculture sector. Production of peach and wheat consumed 369,008,329.2 $2 \mathrm{~m}^{3} /$ year and $345,494,549.78 \mathrm{~m}^{3} /$ year of green and blue water in Tehran, respectively. Besides that, apricot, apple, maize, sour cherry, grapes, cotton, cherry, tomato, pear, and plum consumed $298 \mathrm{MCM}$ (million cubic meter), $119 \mathrm{MCM}, 81 \mathrm{MCM}, 68 \mathrm{MCM}$, $62 \mathrm{MCM}, 45 \mathrm{MCM}, 41 \mathrm{MCM}, 19 \mathrm{MCM}, 13 \mathrm{MCM}$, and $10 \mathrm{MCM}$ of blue and green water resources, respectively. Other crops including potato, melon, watermelon, and onion consumed $9 \mathrm{MCM}, 7 \mathrm{MCM}, 1 \mathrm{MCM}$, and $1 \mathrm{MCM}$ of blue and green water resources, respectively (Figure 2).

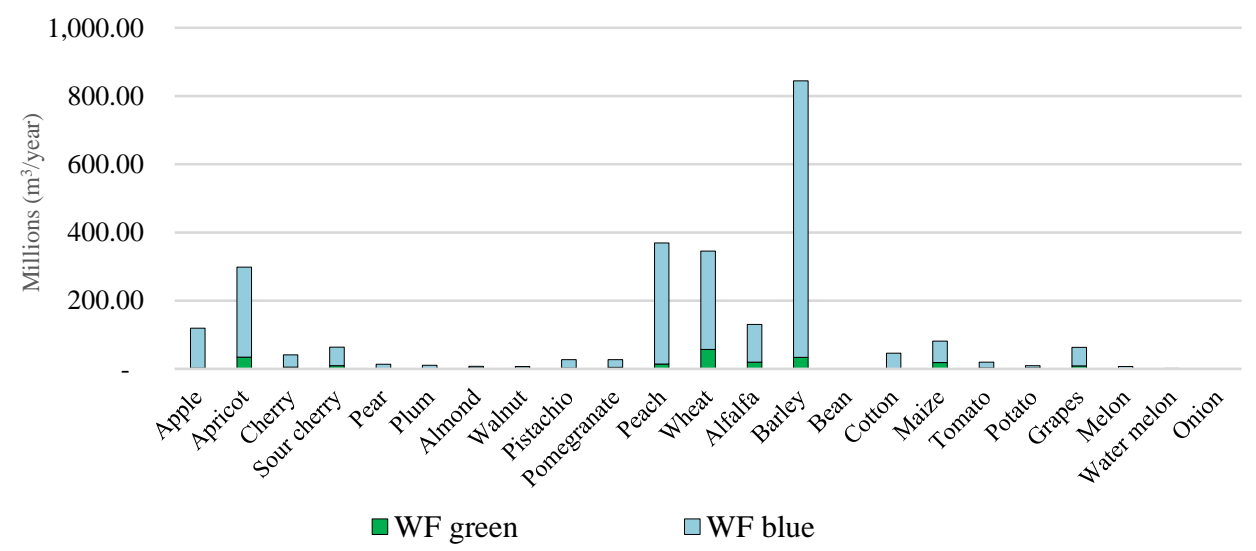

Figure 2 The average blue and green water footprint of crop production in Tehran $\left(\mathrm{m}^{3} /\right.$ year $)$ 
The proportion of crop water footprint in relation to crop production in Tehran province is illustrated in Figure 3. The average total blue and green water footprint during 2007-2015 was 2,422,200,987.18 $\mathrm{m}^{3} /$ year. Barley and peach consumed the largest total water footprint; altogether accounting for $48 \%$ of the total agricultural water footprint in this province. Moreover, wheat and apricot consumed $14 \%$ and $12 \%$ of blue and green water resources in Tehran, respectively (Figure 5). Other crops including apple, cherry, sour cherry, cherry, pear, plum, almond, walnut, pistachio, pomegranate, alfalfa, bean, cotton, maize, tomato, potato, grapes, melon, watermelon, and onion altogether consumed $26 \%$ of the total water footprint.

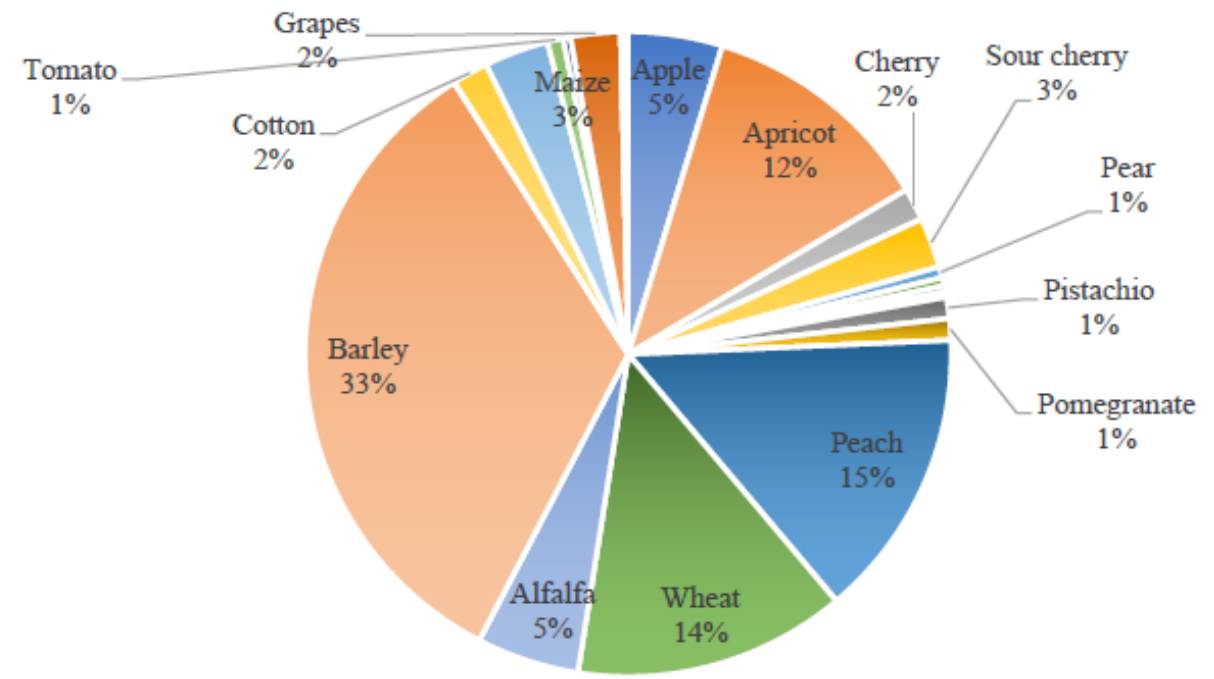

Figure 3 The contribution of water footprint of different crops to the total water footprint of Tehran province

Average total blue water footprint from 2007 to 20015 was $100,392,161.52 \mathrm{~m}^{3} /$ year. Barley and peach had the largest blue water footprint accounting for $35 \%$ and $15 \%$ of the total blue water footprint for Tehran province, respectively. Wheat and apricot consumed $14 \%$ and $12 \%$ of total blue water footprint in agricultural sector. Other crops consumed $25 \%$ of the total blue water footprint (Figure 4). 
PLANNING MALAYSIA

Journal of the Malaysia Institute of Planners (2019)

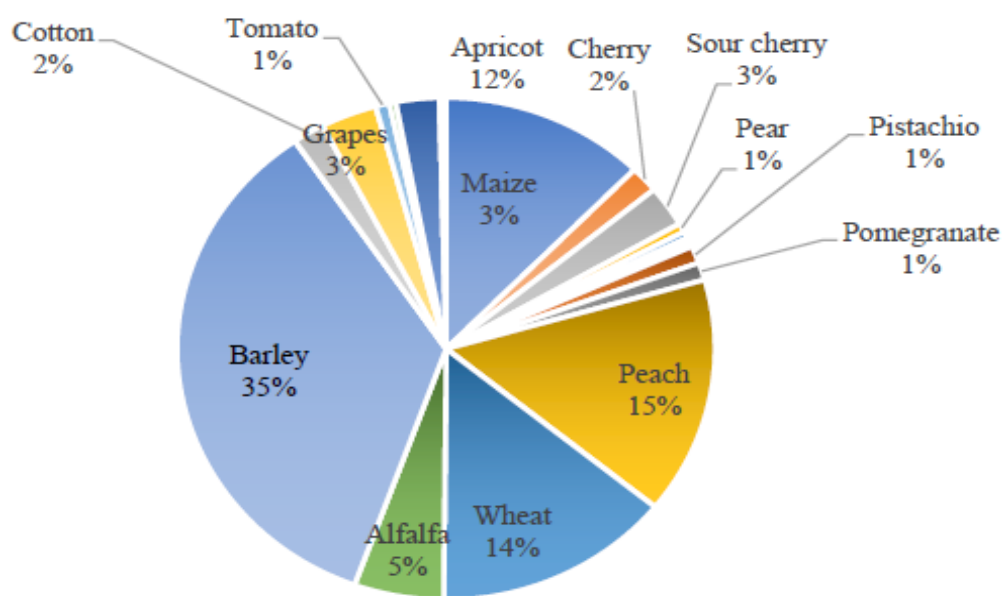

Figure 4 The contribution of blue water footprint of different crops to the total water footprint of Tehran province

The average total green water footprint was 10,132,557.15 m3/year (2007-2015). Wheat and barley have the largest green water footprint. Both account for $40 \%$ of the total green water footprint in Tehran province. Apricot consumed $15 \%$ green water resource, which amounted to $34 \mathrm{MCM} /$ year. Maize and alfalfa contributed the same ratio of green water footprint, which accounted for $18,736,933 \mathrm{~m} 3 /$ year and $19,971,664 \mathrm{~m} 3 /$ year, respectively, or $8 \%$ of the total green water footprint. Other crops altogether consumed $29 \%$ of total green water footprint in Tehran. Besides that, all of the fruits contributed to $41 \%$ of the total water footprint in Tehran (Figure 5).

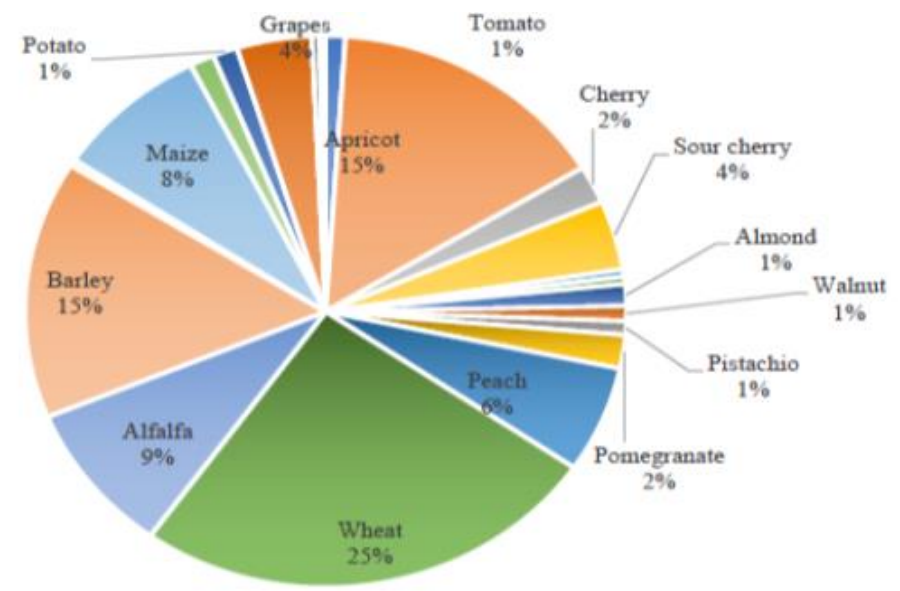

Figure 5 The contribution of green water footprint of different crops to the total water footprint of Tehran province 
Somayeh Rezaei Kalvani, Amir Hamzah Sharaai, Latifah Manaf, \& Amir Hossein Hamidian

Water Footprint of Crop Production in Tehran Province

\section{Water footprint trend in Tehran}

The total water footprint of crop production in Tehran has increased from 986.857 MCM (2008) to $1,097,738,205.2 \mathrm{~m}^{3} /$ year (2015) (Figure 6). The water footprint of wheat decreased from $366.868 \mathrm{MCM}$ (2008) to $297.899 \mathrm{MCM}$ because productivity increased in 2015 (4.83ton/ha) in comparison to 2008 ( 3.2 ton/ha). The water footprint of all fruits increased because the volume of production was also increased. However, the water footprint decreased from 2009-2011 because productivity increased during these years. The water footprint of alfalfa was increased from $116 \mathrm{MCM}$ to $193 \mathrm{MCM}$ in 2008-2015 (Figure 8). The water footprint of barley increased from $34 \mathrm{MCM} / \mathrm{year}$ to $131 \mathrm{MCM}$ in 2008-2015 because the volume of production has increased. The water footprint for the production of maize increased from $66 \mathrm{MCM}$ to $113 \mathrm{MCM}$.

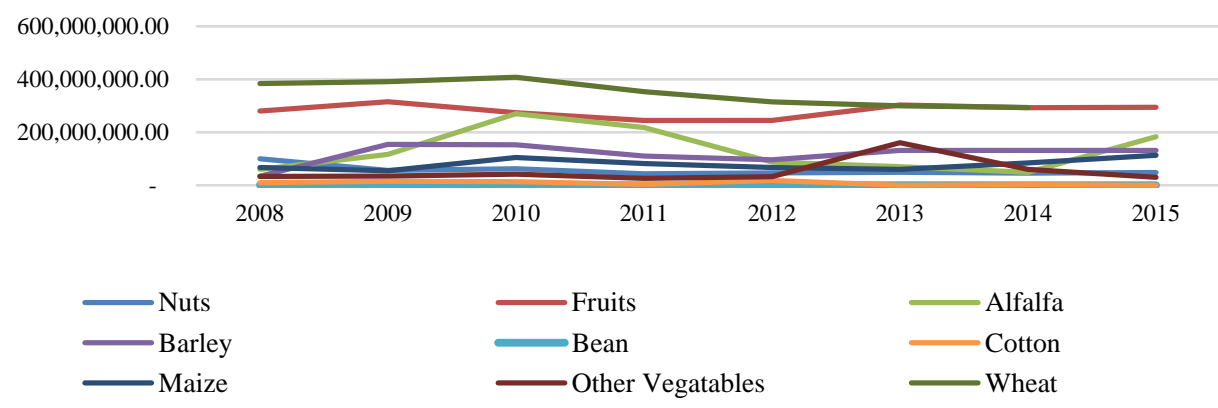

Figure 6 The trend of water footprint (m3/ton) of different crops from 2008 to 2015

\section{Blue water stress in Tehran}

Blue water stress in the agricultural sector in Tehran was evaluated. The blue water stress was 0.64 (high class) in 2015-2016, which indicates high blue water stress in the agricultural sector. This means that the production of agricultural crops in Tehran is unsustainable.

\section{DISCUSSION}

During the period 2008-2015, barley and wheat consumed $1198698827 \mathrm{~m}^{3} / \mathrm{year}$, and approximately $1 / 2$ of agricultural water withdrawal was allocated to the production of these crops in Tehran province. The contribution of green water in the production of cereal was just $8 \%$. The findings from this study suggest that the production of wheat and barley should be reduced since these crops are more dependent on limited blue water resources. Besides that, the production of wheat and barley have the largest water footprint in Tehran in comparison to the global average water footprint (Mekonnen \& Hoekstra, 2010). Additionally, the production of some fruits such as peach and apricot in Tehran should be reduced since these fruits altogether consumed $27 \%$ of the blue water resources in 
Tehran. The water footprint of some crops such as watermelon, melon, and onion is the lowest in Tehran. This study, therefore, suggested increase in the cultivation of these crops, as they have shown the highest productivity.

It is concluded that the water footprint $\left(\mathrm{m}^{3} / \mathrm{ton}\right)$ of crops relies on productivity. Besides that, the water footprint also showed an increasing trend whenever productivity decreased. The green water footprint was the largest footprint contributing to the total water footprint in 2007, but in 2015, this footprint was the lowest because the precipitation in 2015 was lower than 2007 and 2015 was a dry year.

In a previous water footprint assessment of Iran (Ababaei \& Etedali, 2014), the water footprint of cereal production was evaluated on a national scale. This research, however, investigates the water footprint of all crops in the province of Tehran as well as the water footprint trend spanning 9 years. The water footprint of crops (2008-2005) in this this research is slightly larger than the water footprint assessment by Hoekstra (1996-2005) (Mekonnen \& Hoekstra, 2010) because climate and productivity were different.

\section{CONCLUSION}

The total average water footprint (excluding the grey water footprint) for production of crops in Tehran province from 2008 and 2015 was $1,069,096,320.93 \mathrm{~m}^{3} / y e a r$. Blue water footprint contributed the largest footprint (91\%) in the total water footprint for Tehran province because of the climate condition in this province. Total water footprint was slightly increased from $986,857,963 \mathrm{~m}^{3} /$ year $(2008)$ to $1,097,738,205.2 \mathrm{~m}^{3} /$ year $(2015)$. The water footprint in Tehran relies on productivity, which differs from year to year. Reduced productivity contributes to increased total water footprint. The total water footprint in 2015 was higher than that of 2008. Green water footprint is dependent on rainfall. The green water footprint in Tehran increased in the year observing high precipitation. The production of cereal consumed half of the water withdrawal in the agricultural sector. It is suggested that the production of wheat and barley be reduced since the production of these crops relatively depends on limited blue water resources. Besides that, decision makers in the agricultural sector should reduce the production of crops with high water footprint, so as to reduce pressure on water resources in Tehran. Moreover, agricultural blue water scarcity accounted for 0.6 (in the severe class of water stress) in 2015-2016. The WF of crop production depends on productivity and climate condition. The green WF is reliant on rainfall. It is, therefore, suggested that the production of cereal in Tehran be reduced since the production of these crops is highly dependent on limited blue water resources. In the future, the water footprint assessment particularly blue water footprint will be evaluated separately to obtain separate ground and surface water footprints and, in turn, ground and surface water stress, respectively. 
Somayeh Rezaei Kalvani, Amir Hamzah Sharaai, Latifah Manaf, \& Amir Hossein Hamidian

Water Footprint of Crop Production in Tehran Province

\section{ACKNOWLEDGEMENT}

The authors would like to gratefully acknowledge Universiti Putra Malaysia (GP/2018/9592300) for supporting this research project.

\section{REFERENCES}

Ababaei, B., \& Etedali, H. R. (2014). Estimation of water footprint components of Iran's wheat production: Comparison of global and national scale estimates. Environmental Processes, 1(3), 193-205.

Allen, R. G., Pereira, L. S., Raes, D., \& Smith, M. (1998). Crop evapotranspiration Guidelines for computing crop water requirements - FAO Irrigation and Drainage Paper 56. Rome: FAO.

Boer, T. D. (2014). Water footprint assessment of crop production in Shaanxi, China (Thesis). University of Twente, Enschede, the Netherlands.

Hoekstra, A. Y., Chapagain, A. K., Aldaya, M. M., \& Mekonne, M. M. (2011). The water footprint assessment manual. London: Earthscan.

Hoekstra, A. Y., \& Hung, P. Q. (2002). A quantification of virtual water flows between nations in relation to international crop trade. Value of Water Research Report Series No. 11. UNESCO-IHE.

Madani, K. (2014). Water management in Iran: What is causing the looming crisis? Journal of Environmental Studies and Sciences, 4(4), 315-328.

Mekonnen, M., \& Hoekstra, A. (2010). The green, blue and grey water footprint of crops and derived crop products. Value of Water Research Report Series No. 47 (Vol. 2 - Appendices), UNESCO-IHE.

Organización de las Naciones Unidas. (2005). Coping with water scarcity: Challeng of the twenty-first century. Un Water, 24(1), 28-29.

Rijsberman, F. R. (2004). Water scarcity: Fact or fiction? Proceedings of the 4th International Crop Science Congress, 80, 5-22.

Rockstrom, J., \& Falkenmark, M. (2006). The new blue and green water paradigm: Breaking new ground for water resources planning and management. Journal of Water Resources Planning and Management, 132(3), 129-132.

Tillotson, M. R., Liu, J., Guan, D., \& Pahlow, M. (2014). Water footprint symposium: Where next for water footprint and water assessment methodology?, The International Journal of Life Cycle Assessment, 19(8), 1561-1565.

Zehtabian, G., Khosravi, H., \& Ghodsi, M. (2009). High demand in a land of water scarcity: Iran. In G. Schneier-Madanes \& M. Courel (2009). Water and sustainability in arid regions: Bridging the gap between physical and social sciences (pp. 75-86). Berlin: Springer Science \& Business Media.

Xinchun, C., Mengyang, W., Xiangping, G., Yalian, Z., Yan, G., Nan, W., \& Weiguang, W. (2017). Assessing water scarcity in agricultural production system based on the generalized water resources and water footprint framework. Science of the Total Environment, 609, 587-597

Received: $12^{\text {th }}$ January 2019. Accepted: $2^{\text {nd }}$ August 2019 